\title{
National states, transnational institutions, and hegemony in the EU
}

\section{Costas Lapavitsas $^{1}$ (D) $\cdot$ Sergi Cutillas ${ }^{2}$}

Received: 5 May 2021 / Accepted: 9 October 2021 / Published online: 31 October 2021

(C) Japan Association for Evolutionary Economics 2021

\begin{abstract}
The institutional framework of the EU was altered by the pandemic shock of 2020 , introducing greater discretion in both monetary and fiscal policy. The changes relate mostly to monetary policy and cast light on the theoretical debates regarding national states and transnational mechanisms in the EU. Some of the likely implications can be gauged through the balance sheet of the European Central Bank and the operations of the clearing mechanism of TARGET2. Fiscal policy was also transformed due to the threat posed by the pandemic for the euro, thus lifting the framework of austerity. It is notable that the emerging policy framework lacks clear rules, reflecting the peculiar character of German hegemony as well as deep divisions between core and periphery in the EU.
\end{abstract}

Keywords EU · National state $\cdot$ Hegemony $\cdot$ Monetary union · Central bank · TARGET2

JEL Classification F020 · E580 · E610

\section{Introduction: a transformation in policy making}

The pandemic crisis brought multiple changes to monetary and fiscal policy in the European Union, encouraging greater discretion by member states and the Union as a whole. Some of these changes have been in the offing for several years but were held back partly due to the resistance of Germany, the hegemonic country of the EU. Germany partially relented as the pandemic shock threatened the

Costas Lapavitsas

c15@soas.ac.uk

Sergi Cutillas

sergicutillas@ub.edu

1 Department of Economics, SOAS, London, UK

2 Department of Economic History, Institutions, Politics and World Economy, University of Barcelona, Barcelona, Spain 
stability of the euro and even of the EU itself. Discretion replaced rules in economic policy making, as is clearly seen in the operations of the European Central Bank (ECB) but also in fiscal policy.

The pandemic shock also shone a fresh light on the hierarchical nature of the EU, including its division into core and periphery. Member states of the EU attempted initially to confront the crisis by drawing on their national strength and resources. Their actions inevitably meant that growing fiscal deficits pushed up public debt, thus making it difficult for heavily indebted states to access international financial markets. Borrowing rates for peripheral countries escalated rapidly.

The immediate cause of the escalation was the declaration by Christine Lagarde, the President of the ECB, on 12 March 2020, that: "[w]e are not here to close spreads. This is not the function or the mission of the ECB. There are other tools for that, and there are other actors to actually deal with those issues" (ECB 2020). On the wake of this statement, concern about the ability of Italy to finance its public debt soared, posing a direct threat to the euro. By 24 March the ECB had changed course adopting the "Pandemic Emergency Purchase Programme" (PEPP), which soon acquired major dimensions driving interest rates close to zero. The very loose monetary policy of the ECB, going well beyond its original statutes, confirmed the changes originally spurred by the Eurozone crisis of 2010-12.

Fiscal policy also had to adapt to the threat of the pandemic, lifting the rigid framework of austerity that had marked the 2010s. Peripheral EU countries were given scope to boost domestic demand, through automatic stabilisers and active fiscal intervention. Nonetheless, concern about rising public debt forced peripheral countries to strive for a joint EU fiscal response, supported by France. The underlying threat to the euro, and even to the Union itself, led Germany, the hegemonic country, to accede to a joint EU fiscal response, the "Next Generation EU". Although the plan is not particularly large and had not disbursed a single euro well into 2021, its symbolism for the evolution of the EU is not in doubt. Currently, the EU operates without a clear framework of rules of economic policy making.

This article offers an early analysis of these developments in the context of the long-standing theoretical debates on the balance between national states and transnational mechanisms in the EU. It stresses the importance of German hegemony and outlines the characteristic features of core and periphery in the EU. The institutional mechanisms that sustain the core-periphery division within the EU are primarily associated with the European Economic and Monetary Union (EMU) and chiefly the ECB. The euro had profound implications for the tiering of the EU, as is shown by analysing the balance sheet of the ECB and the operations of TARGET2.

Thus, Sect. 2 of the article briefly summarises some relevant academic arguments regarding national states and transnational institutions of the EU; Sect. 3 considers Germany's hegemonic position and its dependence on the transnational mechanisms of the EU; Sect. 4 discusses the institutional transformation of the EU following the outbreak of the Eurozone crisis; Sect. 5 analyses the operations of the ECB focusing on TARGET2, the peculiar clearing mechanism reflecting imbalances between core and periphery within the Eurozone; Sect. 6 briefly examines the lifting of austerity as well as the joint fiscal response of Next Generation EU, and concludes. 


\section{National states, transnational mechanisms, and hegemony in the EU}

Since the 1950s, political and social theorists have engaged in debates regarding the relationship between sovereign national states and the transnational institutions of the EU. The bulk of this literature concurs on the desirability of the European "project" and essentially discusses different ways of promoting integration. However, as the debates proceeded, the "Europe" that emerged was less integrated. While the transnational institutions of the EU became more entrenched and homogeneous, greater divergence prevailed within the Union.

The European "project" presents novel forms of hegemony and division between core and periphery, quite different from the forms of US hegemony after the Second World War. The roots of these developments lie in the political economy of the EU, particularly in a legal framework and a monetary system that extend beyond the confines of national states. The Eurozone crisis of 2010-12 and the pandemic shock of 2020-21 cast a revealing light on relations among national states and transnational bodies in the EU, at odds with the notion of advancing integration.

The bulk of integration analysis has been undertaken by political theorists, especially international relations experts, typically originating in the USA. It is well known that for Ernst Haas, writing in the 1950s, transnational bodies of the EU operating in one field would generate "spill-overs" into other fields, thus gradually expanding the transnational domain (Haas 1958, 1968, 2004). This "neofunctionalist" view pointed toward the steady overcoming of the national state as EU integration proceeded. It fitted well with the mindset of an army of bureaucrats in Brussels and the prevalent top-down technocratic approach to creating the EU.

Haas indeed proposed a general theory of "regional integration" that would be presumably valid across the world, not simply in the EU. It did not take long, however, to become clear that "spill-overs" within the EU were in practice quite limited. The technocratic transnational space of Brussels did not inexorably encroach upon the domain of national sovereignty, a point that Haas eventually came to appreciate (as is clear from the new introduction he wrote for his book in 2004). His theory did not have general applicability, though it retained explanatory power over particular instances of institutional and political development in the EU. ${ }^{1}$

The main theoretical challenge to "neofunctionalism" in the EU was "intergovernmentalism", particularly in its "liberal" form associated with Andrew Moravcsik, another US political theorist (Moravcsik 1998). "Intergovernmentalism" makes the indisputable observation that the EU is a treaty-based alliance of national states. On this basis, it analyses the institutions, events, and policies of the EU as resulting from the give-and-take of the national states bound together by the Treaties. For Moravcsik, national states are agents interacting within a game-theoretic framework largely borrowed from neoclassical economics. The upshot is clear: at the heart of

\footnotetext{
1 See, for instance, the arguments of Schmitter (2005), one of the most prominent supporters of this approach.
} 
the EU lie national states driven by domestic and international interests, not transnational mechanisms with their own independent functioning.

"Liberal intergovernmentalism", despite its claims to theoretical abstraction, is in effect a disciplinary spill-over from the original analysis of the EU by the British historian Alan Milward (Milward 1992). For Milward, the EU was created by the national states of Europe after the Second World War, thus allowing these states to regain legitimacy in the eyes of their people following the disasters of war. At all critical junctures of the creation and deepening of the EU, the main concerns of member states were economic, including mostly trade relations and industrial policy. The European national state, far from surrendering, enhanced its sovereignty via the institutions and policies of the EU (Milward and Sørensen 1993). For Milward, the national state in Europe was rescued by the EU.

Milward's analysis was path-breaking and had the great merit of being historical rather than proposing abstract theories of international relations among national states. To be sure, Milward's main claim was exaggerated since there were plenty of European states that did not need "rescuing" by the EU after the Second World War. Domestic factors, both ideological and material, facilitated the re-emergence of European national states following Hitler's march from one end of the continent to the other. Nonetheless, after Milward's contribution, it was hard to deny that a theoretical analysis of relations among national states and transnational bodies in the EU had to be based on the political economy of capitalism.

Even so, and especially from the perspective of Marxist political economy, it is highly debatable whether a general theory of national states and transnational bodies could ever be constructed. The crucial point in this respect is that the world market, in which national states, private capitals, and transnational institutions interact, is intrinsically anarchic and riven by hierarchical relations of power and dominance. The difference with the domestic market is qualitative. In the domestic market, the national state acts as legal and institutional coordinator, but the market itself already possesses a high degree of spontaneous organisation due to domestic money acting as a measure of value and means of circulation.

The world market also requires a world money to act as means of payment and hoarding, and hence world money is a source of enormous power as well as of crippling weakness for national states (Lapavitsas 2013). But world money does not function as a spontaneous organiser of the world market similarly to domestic money in the domestic market. The world market lacks such an organiser and remains an intrinsically anarchic space of continuous contestation among national states, private capitals, and transnational institutions. It follows that the tools for analysing the world market must be strongly historical and concrete rather than abstractly theoretical.

In this light, the establishment of the European Economic and Monetary Union (EMU) was a critical moment for national sovereignty and transnational relations in the EU. The Eurozone crisis of 2010-12 provided a testing ground for "liberal intergovernmentalism". The main author of this approach and his collaborators claimed that the crisis largely confirmed their theory since the costs of peripheral default and possible euro collapse would have been substantial for all EMU members but significantly higher for countries such as Greece (Moravscik and Schimmelfennig 2019). 
Consequently, an asymmetric bargaining game emerged whereby a "northern coalition" of Germany, Austria, Finland, and the Netherlands imposed its terms on an "southern coalition" (which they do not specify). The adjustment costs were shifted onto the latter and the institutional reforms that took place in the EMU remained limited in scope and power to suit the interests of Germany.

There is no doubt that adjustment in the face of the Eurozone crisis was profoundly asymmetric. But the point is that the asymmetry of power and the concomitant grouping of countries (leaving aside the fact that a "southern coalition" never actually materialised) resulted from the very structures of the EMU. The transnational mechanisms of the monetary union, above all, the elimination of exchange rates and the single monetary policy of the ECB, were the decisive factor in Germany being able to generate an enormous trade surplus, thus having the ability to lend internationally. Analogously, in the absence of the monetary union, Greece and other countries in the periphery of the EU would have been able to devalue their exchange rates, thus giving a vital boost to their economies, as elementary economic theory dictated (Lapavitsas et al. 2017).

The transnational mechanisms of the EMU were vital to the power imbalances manifested during the Eurozone crisis. The unequal bargaining that took place among national states flowed directly from the conditions created by the euro, two of which proved instrumental. The first was the monopoly of the ECB over the creation of liquidity in the EMU, allowing the central bank to put entire national economies in a strangle; the second was the threat felt individually by millions of people that they would lose both their money savings and their identity in case of exit from the EMU. The bargaining between Berlin and Athens occurred within the transnational mechanisms of the EMU, which have their own independent functioning and logic. Berlin was able to impose its terms on Athens, but its dominance was mediated by the balance sheet of the ECB and the other mechanisms of the EU. If it were simply a case of foreign debt, Athens would have probably defaulted early in the crisis.

Put differently, the euro has assumed the mantle of domestic money across the EMU, although it is not truly domestic since it is governed transnationally. The euro has a spontaneous and partial organising function within the EMU since it acts as the domestic money of member states. It is also a form of world money, contesting against the US dollar as a global reserve element and international means of payment. In these regards, the euro is deeply contradictory since its institutional mechanisms act as organisers of the Union, while at the same time propelling Germany to hegemony and confining a raft of member states to a peripheral status of indebtedness and weak growth. Evidence of this hierarchy among the national states of the Eurozone became even more apparent during the pandemic. 


\section{Unplanned and conditional hegemony}

Germany did not plan this course of development when the EMU took shape in the 1990s, and indeed the main push toward monetary union came from France. ${ }^{2}$ Since the 1960s the chief concern of Germany was to prevent sharp appreciations of the Deutschmark by relying on Bundesbank independence in monetary policy (Scharpf 2011). In contrast, France and smaller countries aimed to avoid severe and forced depreciations but within a framework that would give them a powerful say in decision making.

Establishing the EMU in the 1990s represented a qualitative leap because all member-states are formally partners pooling their sovereignty. Germany could presumably be disciplined by the rest within a framework of collective decision making. However, the transnational mechanisms of the euro have their own separate functioning and entail their own results. The actual outcome of the EMU was to propel Germany into a hegemonic position by preventing exchange rate adjustments that would have restored competitiveness within the EMU (Flassbeck and Lapavitsas 2015). The point is, nonetheless, that the ECB is not the Bundesbank, and indeed does not rely on any national state to give it legitimacy to create money. The operations of the euro are not directly controlled by Germany, or any other individual member state. For Germany to be hegemonic, its hegemony must necessarily be mediated by the mechanisms of the EU.

German hegemony is, thus, conditional on the transnational mechanisms of the EU; it has also partly derived from political expediency, an aspect that has marked the history of the EU, often determined by military considerations. The entire European "project" was from the start haphazard, including a multitude of other Cold War organisations that failed to grow in subsequent decades (Patel 2020). The USA was instrumental to the emergence of "Europe" as a counterweight to the Soviet Union during the Cold War, and an anti-communist strain has never been absent from the development of the EU (Gillingham 2016). Moreover, the decisive political acts in the construction of the EU were, without exception, imposed from the top on an unsuspecting public, and even in the face of popular opposition (van Middelaar 2013).

The current outlook of the EU is, nevertheless, profoundly different from the early years of the Union, and is shaped by the EMU as part of the Maastricht Treaty of 1992. The euro complemented the Single European Act of 1986, confirming the steady drift of the EU away from state management of aggregate demand, ownership of economic resources, and social democratic concerns. A decisive step was to re-assert the Four Freedoms of the Treaty of Rome of 1957, namely the freedom to move goods, services, capital, and labour across the internal borders of the Union. After Maastricht, these became individual freedoms sustaining a legal framework that transcends national sovereignty in the EU.

\footnotetext{
2 See, for instance, the analysis of the French debates of the euro as a means of gaining a competitive advantage vis-à-vis Germany in Parguez (2016).
} 
EU law has acquired vast proportions including the "primary" law of the Treaties and the "secondary" law of directives, regulations, decisions, and international agreements. The pivotal institution in this respect is the European Court of Justice, which has gradually arrogated to itself the power of interpreting the law without encroachment by a separate power. The ECJ is a transnational body that holds itself up by its own bootstraps, as it were. It possesses enormous power to shape the legal cogwheels of the EU, which are crucial to the operations of the Single Market and the EMU. In practice, European law has acquired a constitutional character that is superior to national law and impervious to national executive and legislative power (Weiler 1999).

The acquisition of this astounding power was largely unplanned. It began to emerge long before Maastricht with a series of landmark court decisions, notably van Gend en Loos in 1963, which established that the Treaties of the EU have a direct legal effect on persons, enterprises, and others in member states, and Costa in 1964, which established that national law could not override EU law. Of crucial importance was also Dijon de Cassis in 1979 setting the principle of mutual recognition, i.e., that a product lawfully produced and sold in one member state must be accepted by another. Not least were court decisions regarding labour rights, above all, the Viking Line case in 2007 and the Laval case also in 2007, which effectively limited the right to strike and facilitated the "posting" of workers, that is, sending workers to other member states under the conditions of their own member states.

The neoliberal tenor of this legislation is not in doubt, driven as it is by the Four Freedoms and placing enormous constraints on national governments that would wish to adopt interventionist economic policies. Given the superior status of European law relative to national law, a national government could potentially face immediate legal challenges supported by the ECJ. Even worse, a national government would not be able unilaterally to change the legal framework of policy since the latter has a transnational constitutional dimension. ${ }^{3}$

There should be no surprise that the transnational structures of the EU steadily and inexorably promoted the neoliberal evolution of the Union. Already in the 1930s some of the most vocal supporters of neoliberalism strongly supported federalism as a means of limiting the power of national states to intervene in the economy, thus facilitating the free operation of markets (Slobodian 2018). It is well known that Hayek's discussion of federalism during that period remarkably prefigured the neoliberal evolution of the EU. ${ }^{4}$ What is typically absent from these early discussions of federalism, however, is even a slight premonition that hegemony might emerge as the power of national states adjusted to the presence of federal institutions.

German hegemony in the EU is unusual in historical terms. It is rooted in domestic relations in Germany but is articulated through the mechanisms and institutions

\footnotetext{
3 These constraints were a heated point of argument at the peak of the Brexit controversy in the UK, shown with great clarity by Tuck (2020).

${ }^{4}$ For further discussion of Hayek's views on federalism and the EUs, see Lapavitsas (2018a). It is less appreciated in the literature that Hayek's arguments were also aimed against the socialist organisation of the economy. This is abundantly clear in Robbins' contributions to the debates, see, for instance, Robbins (1968) [1939].
} 
of the EU. Unlike the USA, which created the global institutions that express its economic and political hegemony after the Second World War, Germany has become hegemonic by operating within institutions established jointly by EU member states and often following the initiative of others, above all, the EMU. Its hegemony would not exist in the absence of EU institutions.

As Germany became hegemonic, the EU acquired several peripheries, most notably in the South. The distinctions between EU core and periphery are shifting and loose, while remaining real, as is the norm with historical phenomena of this magnitude (Lapavitsas 2018a). The patterns of dominance over the periphery derive, first, from the common currency with its extensive battery of institutions and, second, from the spread of German industrial capital across much of the EU. Suffice it to mention two EU peripheries: the first is in Southern Europe, formed by Spain, Portugal, and Greece, operating within the EMU, with a weakened industrial sector and being heavily indebted to the core; the second is in Central and Eastern Europe, formed by Poland, Hungary, the Czech Republic, Slovakia, and Slovenia, operating partially outside the EMU, and comprising countries that are integrated in Germany's industrial production chains.

\section{The institutional transformation of the EU after the Eurozone crisis}

The Eurozone crisis, 2010-12, launched a series of institutional transformations that are crucial to German hegemony as well as to the functioning of the EU following the pandemic crisis. Economic analysis dictated that the EMU required a rebalancing of competitiveness, while imposing some of the costs of adjustment onto Germany as the dominant exporter and financier of the EU. Instead, the EU minimised costs for Germany and offered bailouts accompanied by internal deflation to peripheral countries. Severe austerity was supposed to eliminate fiscal and current account deficits, while deregulation of labour and product markets would presumably restore international competitiveness. The driving force behind these policies was to be found in Berlin.

Several institutional transformations of the EU ensued, marking the evolution of the Union prior to the pandemic shock. Germany entrenched its hegemony, while leading the EU into economic and political stagnation. In 2011-12, the Fiscal Pact, the Six-Pack, and the Two-Pack reforms were signed, deepening the Stability and Growth Pact that set the terms of fiscal policy and public debt in the EU. These reforms inscribed austerity into the constitutional framework of the EU, but were complex, very detailed, and inherently dysfunctional, thus in practice leaving room for manoeuvre to member states.

New institutions were also created to manage the bailouts and their financial repercussions. In May 2010 the European Financial Stability Fund (EFSF) and the European Financial Stability Mechanism (EFSM) came into existence. The EFSF was the more important of the two, created as a private institution, located in Luxembourg and operating under British law. The intention was to avoid explicitly contravening the so-called no-bailout clause, that is, article 125 of Treaty on the Functioning of the EU (EU 2016a). This action was fundamental to operating the bailouts 
of peripheral countries, and typical of how the institutional transformation of the EU was to proceed. The letter of the Treaties would be formally observed but their spirit would be ignored when urgent action was inevitable. No institution demonstrates this more clearly than the ECB, as is shown below.

A few months later, in December 2010, Article 136 of the Treaty was rapidly amended to provide a legal foundation for the permanent successor of the EFSF, the European Stability Mechanism (ESM). The ESM was created by the European Council in March 2011 through an inter-governmental treaty subject to international law. It is an organisation financed by issuing debt in the open markets and supported by guarantees from the member states of the Eurozone. The aim is to confront crises by providing loans on terms broadly shaped by policies of austerity and deregulation. Germany insisted that the ESM would have a credit limit set at 500 billion euros, which is substantial but not enough to allow the ESM to act as a European International Monetary Fund.

Two key institutional changes of the EU were, however, resisted by Germany. First, there would be no formal lender of last resort in the Eurozone: the mandate of the ECB remained formally the same, continuing to forbid the financing of state deficits in line with article 123 of the Treaty on the Functioning of the EU (EU 2016b). Second, there would be no issuing of Eurobonds that would formally create mutual responsibility for public borrowing within the EU. Germany strongly resisted assuming responsibility for the costs of public finance in other member-states.

Nonetheless, in July 2012, Mario Draghi, the Governor of the ECB, proclaimed that he would do "whatever it takes" to save the euro, thus setting in motion an extraordinary programme of purchasing government bonds. This step pacified the Eurozone crisis and was a defining moment in recent EU history, not least because it ushered in the gradual transformation of the ECB, laying the ground for its intervention in the pandemic crisis.

The changed role of the ECB must be seen in conjunction with further steps taken to reform banking and finance across the EU hoping to prevent a repetition of the Eurozone crisis. The reforms focused, first, on strengthening the capital and liquidity requirements of banks, second, on implementing recovery and resolution regulations on failing banks to limit the liability of taxpayers for losses, and third, legally separating risky financial activities from the practices of deposit-taking banks (Liikanen et al. 2012).

The reforms were part of a putative drive toward a Banking Union across the EU that would eliminate public bailouts of private banks, thus presumably "completing" the monetary union. The Banking Union included the Single Supervisory Mechanism allowing the ECB to supervise large and small banks in the EU, and the Single Resolution Mechanism to provide public funds in the event of bank failure and restructuring. To preclude public bailouts, the mechanism was not allowed to disburse funds until the shareholders and bondholders would have borne losses equal to at least $8 \%$ of a bank's liabilities (Bellia and Maccaferri 2020).

Despite establishing new institutions, progress toward Banking Union was very limited, above all, since a Deposit Guarantee Fund was not created. If banks faced major risks of default in the future, they would also probably face a severe drain on their deposits, thus creating a potentially destructive mix of solvency and 
liquidity problems. For large banks, that would immediately threaten the stability of the domestic banking system as well as potentially threatening banking relations across the EU. The Banking Union would never be complete without a mechanism to deal with this risk, including a lender of last resort.

Nonetheless, the bureaucracy of Brussels also pushed ahead with further institutional reforms, including a Capital Markets Union that intended to homogenise securities trading within the EU facilitating a shift toward more strongly market-based finance. A perennial reform aim was the joint issuance of short- and medium-term debt to facilitate the integration of financial markets (European Commission 2012). Equally persistent was the notion of creating a self-supporting EU budget to provide the EMU with fiscal capacity to absorb shocks. Perhaps the most ambitious ideas, however, were to be found in the so-called Report of the Five Presidents proposing the deepening and the completion of EMU by 2025, no less (Juncker et al. 2015).

By early 2020 few of the grand notions of "completing" the EMU had taken institutional form, and the EU had suffered a decade of institutionalised austerity. The pandemic shock posed a very different problem from the Eurozone crisis of 2010-12 since it led to a collapse of aggregate demand while severely disrupting aggregate supply. It then became clear that the ECB had steadily changed its mode of operation in the preceding years and was able to assume centre stage in confronting the crisis. At the same time, the EU took rapid steps to lift the constraints of austerity on member-states.

The response of the EU to the pandemic was very different to the Eurozone crisis. The differences can be seen in terms of central bank policy, member-state fiscal policy, state aid policy, and the joint programme for fiscal intervention. Taken together they signal a pragmatic shift in the policy framework of the EU, while casting a sharp light on relations between sovereign countries and transnational bodies.

\section{An interventionist ECB}

The ECB has emerged as the pre-eminent economic institution of the EU acting in ways that digress from its original statutes, not least by operating quantitative easing in the 2010s and engaging in an enormous expansion of its balance sheet in 2020-21. There is no evidence that the changes in the role of the ECB have resulted from intergovernmental bargaining. Rather, Germany appears to have acceded to actions emanating from within the ECB as practical adjustments to quantitative easing. During the Eurozone crisis, it became clear that the hegemonic position of Germany depends on the survival of the euro, which in turn relies on the ECB acquiring substantial powers of discretion in monetary policy. The transformation of the ECB began to take shape.

The nature of the transformation first emerged in the second half of the 2010s. The ECB is presumably not allowed to buy state debt according to article 123 of the Treaty on the Functioning of the EU, signed in Lisbon in 2007. This norm was sidestepped in 2014-15, when the ECB systematically engaged in quantitative easing (the so-called Asset Purchase Programme, APP). The APP consisted of four smaller programmes namely, the Corporate Sector Purchase Programme (CSPP), the Public 


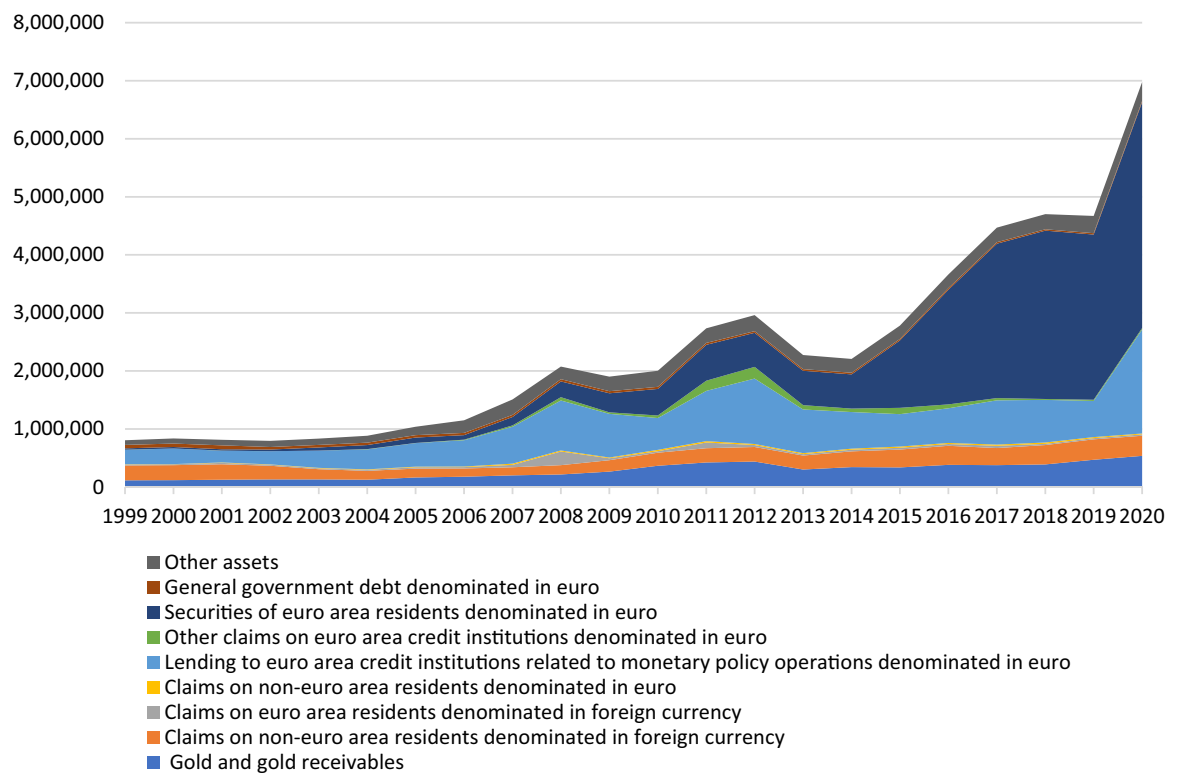

Fig. 1 Eurosystem consolidated balance sheet. 1999-2020. (Euro millions, outstanding amounts at end of December). Source: ECB

Sector Purchase Programme (PSPP), the Asset-Backed Securities Purchase Programme, and the third Covered Bonds Purchase Programme (CBPP3) (ECB 2021a).

After 2014-15, the balance sheet of the Eurosystem, which comprises the National Central Banks of member-states and includes the ECB as a separate entity, grew enormously, as is shown in Fig. 1:

During 2015-21 substantial monthly purchases took place, eventually resulting in the ECB holding securities worth 3 trillion euros by early 2021. It is important to note the jump in the assets of the ECB and the Eurosystem after the outbreak of the pandemic crisis. The increase was partly due to provision of liquidity to banks via the ECB's Long-Term Refinancing Operations (LTRO), that is, via preferential loans offered to banks at low-interest rates backed by collateral and lasting for three years, an instrument that had also been heavily deployed in the Eurozone crisis. The real change, however, was the great increase in assets due to the purchases of securities under the Pandemic Emergency Purchase Programme (PEPP). The PEPP was effectively the continuation of APP, as is clear from Fig. 1.

By early 2021 the holdings of the ECB had come to include a great proportion of public bonds, shown in Fig. 2:

Although these policies were originally introduced in the 2010s, ECB interventions remained generally constrained for several years, first, by the principle of allocating securities purchases across jurisdictions on the basis of each country's "capital key", that is, the proportion of its contribution to ECB capital; second, by the limit of $33 \%$ of the proportion of a country's public bonds that the ECB could purchase; and third, by strict eligibility requirements for the securities that could 


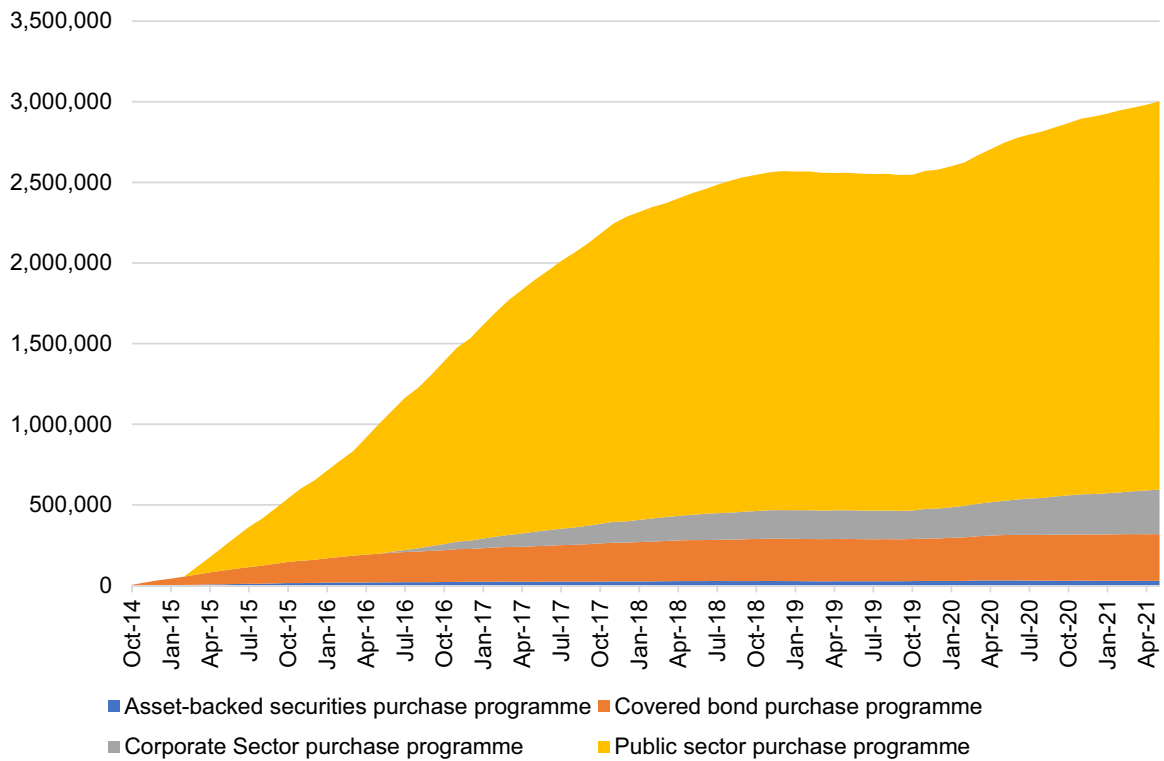

Fig. 2 Eurosystem holdings under the Asset Purchase Programme. (Euro millions, outstanding amounts at end of month, October 2014 to May 2021). Source: ECB

be made available to the ECB. All these constraints were considerably relaxed in response to the pandemic crisis, boosting the discretionary power of the ECB.

The institutional leap was so significant that the German Federal Constitutional Court came forth with the Weiss Judgement, declaring that the ECB and ECJ violated EU law by failing to apply correctly the principle of proportionality in monetary policy. In effect, following the logic of the German court, the ECB acted beyond its powers when it engaged in PEPP to confront the threat of the pandemic crisis, and the policy was unlawful.

There is no doubt that there are profound issues of democratic practice in the acquisition of such enormous powers of discretion by the ECB, an inherently unaccountable institution detached from individual national states. The German Constitutional Court touched upon these issues, including the question of sovereignty, even if from a conservative standpoint, leading to a flood of legal commentary. ${ }^{5}$ For our purposes, what matters is that, despite the debate, the ECB in practice ignored the decision of the German Constitutional Court, with the connivance of the German government. The material interests of hegemony were far too important to be jeopardised by the Constitutional Court.

Consequently, the ECB was able to compress the interest rate spreads between core and periphery in 2020-21, thus acting once again as guarantor of the euro. A notable divergence emerged with EU countries that are outside the EMU, as is

\footnotetext{
5 For discussion from a critical legal perspective that fully appreciates the institutional change of the ECB and the political economy of the evolution of the EMU, see Dani et al. 2021).
} 


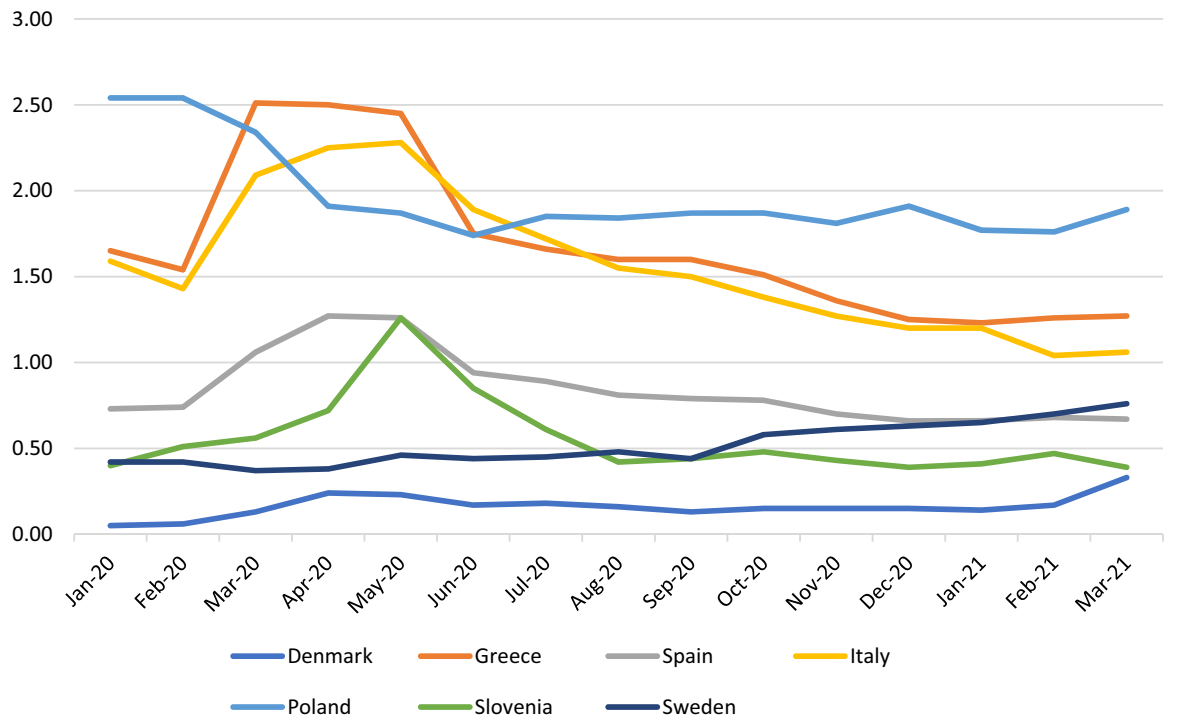

Fig. 310 year bond interest rates spread with German bonds. (January 2020 to March 2021). Source: Eurostat

shown in Fig. 3. Thus, Poland, Denmark, and Sweden (outside the EMU) did not register the jump in spreads early in the crisis that is visible for Italy, Greece, Spain, and Slovenia (inside the EMU). However, spreads outside the EMU were persistent and even increased as fiscal deficits emerged across the EU. In other words, the ECB was able to neutralise the effect of fiscal expansion.

Nevertheless, the expansion of the Eurosystem balance sheet during the pandemic crisis still had a strong national character, with National Central Banks carrying most of the burden of buying securities and lending to banks in their national territory. In early 2021 the Eurosystem unconsolidated balance sheet was more than 11 trillion euros, of which the ECB held less than 2 trillion, while the rest was held by the National Central Banks. The actual proportion of public debt held directly by the ECB was roughly $8 \%$, providing a truer indication of the mutualisation of debt in the Eurozone (ECB 2021b).

Despite the change in the operations of the $\mathrm{ECB}$, central banking in the EU remains very different from the federal system of the USA. The securities bought by the twelve federal reserve banks that comprise the Federal Reserve System bear no relation to the fiscal policies pursued by the region covered by each constituent bank. In contrast, the national deficits of EMU member states are largely financed by the National Central Banks, under the auspices of the Eurosystem.

Indeed, there is no such thing as one central bank with one balance sheet for the euro, since in addition to the balance sheet of the ECB, each National Central Bank has its own balance sheet. The separation of balance sheets reflects the imbalances generated when money capital moves among EMU member-states. The accounting procedures require the central bank of the country receiving money capital to register the inflow on its balance sheet as an additional liability, while the asset stays 
on the balance sheet of the central bank that originally remitted money capital. The receiving central bank adds a balancing item to reflect holding more euros on its balance sheet than it originally created, and the opposite is true for the sending central bank. This balancing item-the TARGET2 balance-is an asset for the receiver and a liability for the sender, both relative to the ECB.

TARGET2 is fundamentally a clearing mechanism among central banks as well as private enterprises in Europe. However, it also reflects the inner workings of the euro as means of payment and hoarding among EMU members. If EMU members related to each other internationally through their own currencies, a current account deficit or a money capital net outflow would have amounted to a loss of international reserves, typically held by a country's central bank. If the loss of reserves persevered, the country would face the prospect of exchange rate depreciation possibly leading to a foreign exchange crisis. The opposite would obviously hold for a current account surplus or a money capital inflow.

Within the EMU, this mechanism has been eliminated. A country with a current account deficit or a net capital outflow would not lose reserves, since there are none, instead its central bank would acquire TARGET2 liabilities. The central bank of a country with a current account surplus or a capital inflow, on the other hand, would accumulate TARGET 2 credits.

In the world market, reserves of international means of payment play a largely passive role for long periods of time, particularly while commodity and money capital flows are behaving "normally". The crucial importance of reserves emerges in times of crisis, and at those times control over available reserves becomes a matter of hegemonic power. The hegemon must handle the creation of reserves both tactically and strategically to prevent a collapse of trade and capital flows. It is a commonplace that managing the reserve role of the dollar internationally is an integral element of US hegemony.

TARGET2 balances play a similarly passive role, except when conditions in the international flows among EMU members become "abnormal". In such times, TARGET2 precludes the possibility of a foreign exchange crisis, since a country with a deficit or net capital outflows would not run out of reserves, but rather its central bank would accumulate liabilities ("red ink"). Analogously, a country with a surplus or net capital inflows would accumulate assets ("black ink"). TARGET2 transforms the strategic management of reserves to avoid systemic crises into the strategic management of the balance sheet of the Eurosystem, again to avoid systemic crises. Unlike the USA in the world market, the hegemonic position of Germany in the international flows among EMU members is necessarily conditional on the ECB.

TARGET2 balances thus cast light on the underlying structure of the EMU, as is shown in Fig. 4:

The TARGET2 assets of the German Bundesbank have reached gigantic proportions since the outbreak of the Great Crisis of 2007-9, partly because of the Eurozone crisis and partly reflecting the quantitative easing policies of the ECB since 2014-15. Essentially, the ECB has facilitated the export of money capital from peripheral countries to Germany in the second half of the 2010s.

Following the outbreak of the pandemic crisis and the surge in quantitative easing by the ECB in 2020, the assets of the Bundesbank exceeded 1.1 trillion 


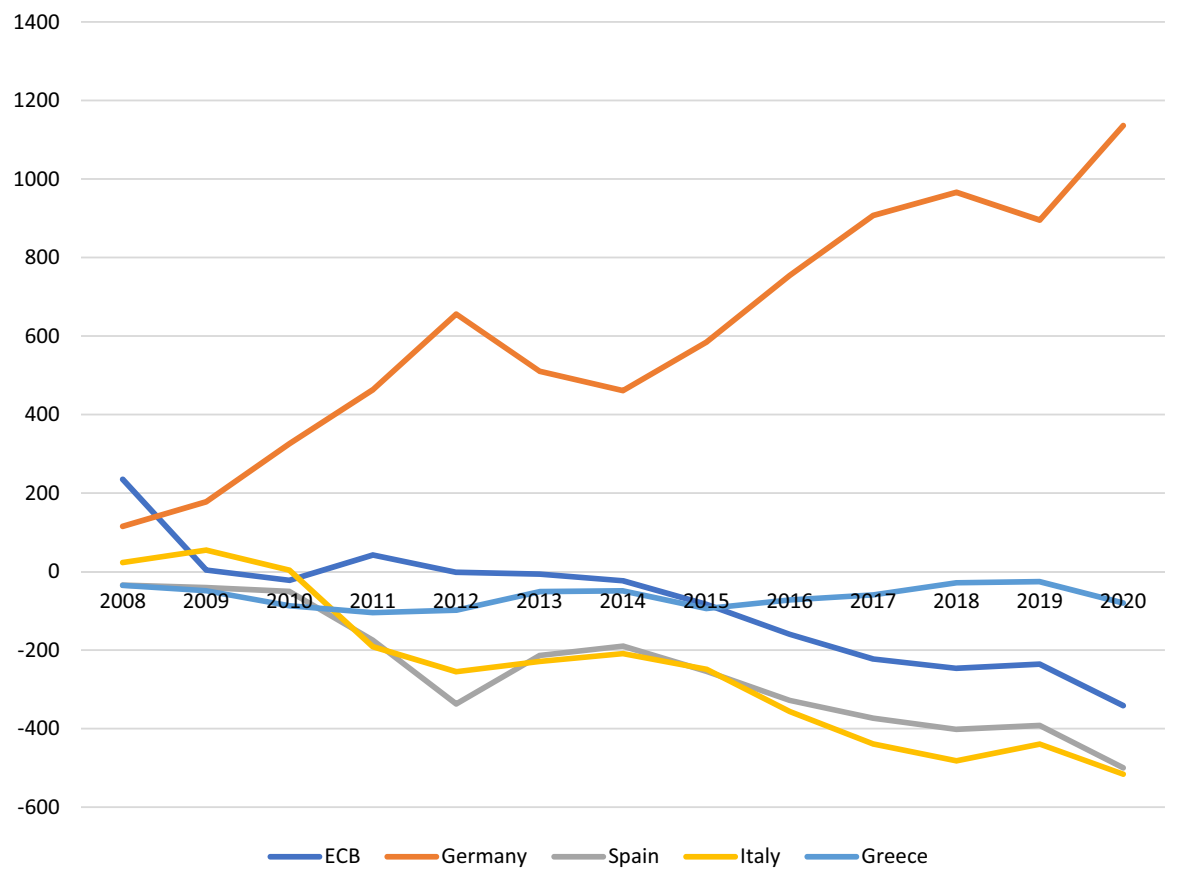

Fig. 4 Target 2 balances. (Euro billion, 2008-2020). Source: ECB

euros in early 2021, while the liabilities of the Bank of Italy and the Bank of Spain reached roughly 500 billion each. During the same period, the liabilities of the Bank of Greece escalated toward 90 billion. The compression of interest rate spreads by the ECB (facilitated by the acquisition of securities also shown as ECB liabilities in Fig. 4) was matched by the exacerbation of imbalances within TARGET2. The process is certainly not identical across peripheral countries, particularly as Italy registered substantial current account surpluses in 2020, but there is no doubt about the direction of development.

The hegemonic position of Germany in this regard is expressed as tacit support for the quantitative policies of the ECB not only by ignoring their legality but also by tolerating the huge accumulation of "black ink" by the Bundesbank within the Eurosystem. TARGET2 assets are a token of German hegemony and not a subsidy of German taxpayers to the feckless periphery of the EMU, as has been falsely claimed within the German establishment (Sinn and Wollmerhäuser 2012). Without the "black ink" of the Bundesbank there would have been no euro and no German hegemony in the EMU. This still leaves open the question of what would happen to TARGET2 balances in case of a country exiting the EMU. The answer is far from clear in legal terms, but it is no coincidence that TARGET2 operates under the jurisdiction of Frankfurt am Main tribunals (Lapavitsas 2018 b). It would be extremely difficult for "red ink" countries to exit the framework without major costs. 


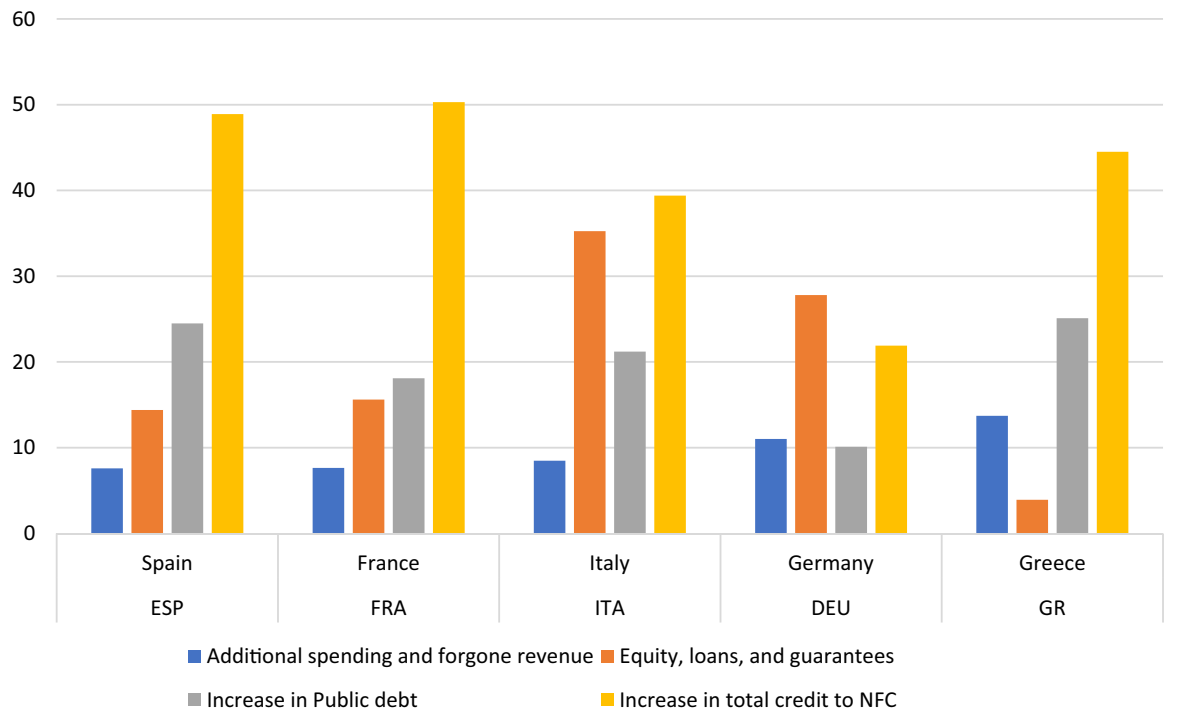

Fig. 5 Policy response to the Covid-19 crisis (from January 2020 to March 2021) and increase in Debt (end 2019 to end 2020 YoY) in Spain, France, Italy, Germany and Greece. (\% of GDP). Source: IMF, Eurostat and BIS. Note: Data on additional spending and foregone revenue as well as on equity, loans and guarantees was extracted from the IMF Fiscal Monitor Database of country fiscal measures in response to the COVID-19 pandemic. Data on the Increase in Public Debt was extracted from Eurostat's Government deficit and debt statistics series. Data on the increase in total credit to non-financial corporations was extracted from the Bank of International Settlements database on credit to the non-financial sector

\section{The lifting of austerity}

At the same time, the EU was forced to lift the fiscal straight-jacket of austerity. The Stability and Growth Pact was suspended, individual member-states gained considerable fiscal discretion and deficits escalated rapidly (IMF 2021). Moreover, the EU suspended regulations governing state aid to the industry as well as other rules that presumably provided a "level playing field" of competition. Member states were able to support their industries according to their resources and discretion. The jump in fiscal expenditure is apparent in Fig. 5:

For countries in the Southern periphery of the EU, including Italy, these policies afforded scope to support domestic demand, partly through automatic stabilisers and partly through active fiscal intervention. Peripheral states also obtained greater freedom to intervene on the side of supply offering support to selected industries. However, member states in the Southern periphery remained burdened with high public indebtedness, a major constraint despite the fall in interest rates.

The threat to both the EMU and the EU led Germany to back France in devising a joint fiscal response, which took the form of the "Next Generation EU", supposed to provide 750 bn euro obtained by the EU Commission through borrowing in the open financial markets. The programme effectively circumvented 
the Treaties-which are the "primary law" of the EU-based on the loose phrasing of article 311 of the Treaty on the Functioning of the European Union. This article states that: "The Union shall provide itself with the means necessary to attain its objectives and carry through its policies" but immediately continues: "Without prejudice to other revenue, the budget shall be financed wholly from own resources" (EU 2008). Faced with the pandemic crisis, discretion trumped rules, and the European Commission took it upon itself to borrow in the open markets to finance the programme.

The plan aims to split the funds into 360bn of loans and 390bn of grants heavily directed toward states in the peripheries of the EU. The monies would become available for entrepreneurial projects, preferably public-private partnerships, submitted by individual countries and aiming at a "green", "digitised" and "inclusive" transformation of their economies (EU 2020). In effect, the programme stands for a kind of industrial policy and represents an important step by the EU in this field. According to the EU Commission, the funds ought to facilitate recovery from the pandemic, and should be directed mostly to Small and Medium Enterprises.

The crucial component of the programme are the grants, representing fiscal transfers to peripheral countries. The planned size of the transfers is not large compared to the GDP of the EU, which stands at roughly 14 trillion euro after the departure of Britain in 2020. Indeed, the programme is decidedly modest, and its importance is primarily political. The fiscal grants that the Southern periphery of the EU would receive for three years are unlikely to exceed $2 \%$ of GDP annually, on a net basis. As for the loans made available to peripheral states, they would probably have a lower rate of interest than for sovereign debt in the open markets, given the top credit rating of the European Commission. Peripheral countries could perhaps save a modest part of the annual interest corresponding to the interest spread between German and peripheral debt over several decades, which is not negligible but is hardly a decisive boost to their economies.

Three further issues stand out. First, the objectives of the fiscal programme are not based on the development needs of peripheral countries to determine the sectoral allocation of funds. The technical analysis accompanying the programme makes clear that the sectors that would absorb the bulk of the funds have largely been chosen by their export potential for core countries as well as to support the presence of the EU in the world market (European Commission 2020). There is no evidence that the optimal industrial strategy for, say, Spain and Greece, following the pandemic and the preceding decade of austerity, ought to comprise "greening" the economy and promoting "digitalisation". Second, given the opacity and lack of democratic control over the programme, it is debatable whether the funds would be distributed by member state governments in favour of powerful domestic capitalist groups. Third, peripheral countries that decide to obtain the loans of the programme would do well to remember the harsh conduct of the EU as a lender to Greece in the 2010s.

Perhaps the most important issue in this respect, however, is whether the fiscal reforms will be sustained (Dani et al. 2021). Unlike monetary policy, there is considerable uncertainty attached to the future path of fiscal policy. It is unlikely that the Stability and Growth Pact will be revived once the shock of the pandemic has passed, but Germany might again insist on fiscal rigidity in the face of augmented 
public debts of peripheral countries. There is also no guarantee that joint fiscal expenditure will become a regular practice within the EU. Nonetheless, the steady drift toward discretion and away from rules that was confirmed by the pandemic is likely to continue.

\section{Conclusion}

The response of the EU to the pandemic crisis in 2020-21 points to significant changes in its institutional structures with profound implications for monetary and fiscal policies. The changes began to take place during the Eurozone crisis of 2010-12 and advanced rapidly in the pandemic crisis, focusing mostly on the ECB and fiscal austerity. Provision of liquidity and purchase of public securities by the ECB reached unprecedented levels, in practice transgressing the regulatory framework of the EMU. Fiscal policy came to include jointly financed cross-state transfers. Discretion has become more important than rules in operating the monetary union and more broadly the EU.

These developments cast fresh light on the division of the EU into core and periphery and the hegemonic role of Germany. The conduct of the EU has long been analysed in terms of a putative conflict between national states and transnational institutions. However, the policies adopted since the Eurozone crisis are more compatible with German hegemony being conditional on, and exercised through EU institutions. In particular, the performance of TARGET2 indicates that Germany is prepared to tolerate the ECB transgressing the spirit of its statutes to protect the euro. Far from being unbending, hegemonic Germany has demonstrated its flexibility in supporting the EU and the EMU. Germany will need all its flexibility in the years ahead as discretion has effectively trumped rules in EU economic policy making.

\section{Declarations}

Conflict of interest On behalf of both authors, the corresponding author states that there is no conflict of interest.

\section{References}

Bellia M, Maccaferri S (2020) Banks' bail-in and the new banking regulation: an EU event study. European Commission JRC Technical Report. JRC Working Papers in Economics and Finance, 2020/07. Publications Office of the European Union, Luxembourg. Available at: https://publications.jrc.ec. europa.eu/repository/handle/JRC119672?mode=full

Dani M, Chiti E, Mendes J, Menéndez A, Schepel H, Wilkinson M (2021) "It's the political economy ..."” A moment of truth for the eurozone and the EU. Int J Const Law 19(1):309-327

ECB (2020) Press conference, Christine Lagarde, President of the ECB, Luis de Guindos, Vice-President of the ECB, Frankfurt am Main, 12 March 2020. Available at: https:/www.ecb.europa.eu/press/ pressconf/2020/html/ecb.is200312 f857a21b6c.en.html 
ECB (2021a) Asset Purchase Programmes. Available at: https://www.ecb.europa.eu/mopo/implement/ app/html/index.en.html

ECB (2021b) Statistical warehouse, breakdown of the Eurosystem aggregated balance sheet. Available at: https://sdw.ecb.europa.eu/reports.do?node $=1000005533$

EU (2008) Consolidated version of the Treaty on the Functioning of the European Union-Part six: institutional and financial provisions. Available at: http://data.europa.eu/eli/treaty/tfeu_2008/art_311/oj

EU (2020) Recovery plan for Europe. Available at: https://ec.europa.eu/info/strategy/recovery-planeurope_en\#nextgenerationeu

EU (2016a) Consolidated version of the Treaty on the Functioning of the European Union. Part threeunion policies and internal actions. Title VIII-economic and monetary policy. Chapter 1 -economic policy, Article 125. Available at: http://data.europa.eu/eli/treaty/tfeu_2016/art_125/oj

EU (2016b) Consolidated version of the Treaty on the Functioning of the European Union, Part threeunion policies and internal actions. Title VIII-economic and monetary policy. Chapter 1 -economic policy, Article 123. Available at: http://data.europa.eu/eli/treaty/tfeu_2016/art_123/oj

European Commission (2012) Communication from the Commission 'A blueprint for a deep and genuine economic and monetary union: Launching a European Debate' COM (2012) 777 final/2. November, 30. Available at: http://ec.europa.eu/archives/commission_2010-2014/president/news/archives/ 2012/11/pdf/blueprint_en.pdf

European Commission (2020) Commission staff working document. 'Identifying Europe's recovery needs'. Available at: https://ec.europa.eu/info/sites/info/files/economy-finance/assessment_of_econo mic_and_investment_needs.pdf

Flassbeck H, Lapavitsas C (2015) Against the Troika: crisis and austerity in the Eurozone. Verso, London and New York

Gillingham J (2016) The EU: an obituary. Verso, London/New York

Haas E (1958, 1968, 2004) The uniting of Europe: political, social, and economic forces, 1950-1957. University of Notre Dame Press, Notre Dame

IMF (2021) Fiscal policy response to COVID19. Available at: https://www.imf.org/en/Topics/imf-andcovid19/Fiscal-Policies-Database-in-Response-to-COVID-19

Juncker JC, Tusk D, Dijsselbloem J, Draghi M, Schulz M (2015) 'The Five Presidents' report: completing Europe's economic and Monetary Union'. Part of collections: background documents on economic and monetary union. First published on 22 June 2015. Available at: https://ec.europa.eu/info/sites/ default/files/5-presidents-report_en.pdf

Lapavitsas C (2013) The Eurozone crisis through the prism of world money. In: Wolfson M, Epstein J (eds) The Handbook of the political economy of financial crises. Oxford University Press, Oxford and New York, pp 378-394

Lapavitsas C (2018a) The left case against the EU. Polity Press, Cambridge, UK and Medford

Lapavitsas C (2018b) The redenomination risk of Eurozone exit for Greece. ifo DICE Report, ifo Institute-Leibniz Institute for Economic Research at the University of Munich, vol 16, issue 3, pp $31-34$

Lapavitsas C, Mariolis T, with a contribution by C. Gavrielidis (2017) Eurozone failure, German policies, and a new path for Greece: policy analysis and proposals. Rosa Luxemburg Stiftung Publikationen, January. Available at: https://www.rosalux.de/en/publication/id/14546/eurozone-failure-germanpolicies-and-a-new-path-for-greece

Liikanen E et al (2012) High-level expert group on reforming the structure of the EU banking sector. Brussels, October 2012. https://ec.europa.eu/info/sites/info/files/liikanen-report-02102012_en.pdf

Milward A (1992) The European rescue of the nation-state. Routledge, London

Milward A, Sørensen V (1993) Interdependence or integration? A national choice. In: Milward A, Lynch F, Romero F, Ranieri R, Sørensen V (eds) The frontier of national sovereignty. Routledge, London, pp 1-32

Moravcsik A (1998) The choice for Europe: social purpose and state power from Messina to Maastricht. Cornell University Press, Ithaca

Moravscik A, Schimmelfennig F (2019) Liberal Intergovernmentalism. In: Wiener A, Börzel T, Risse T (eds) European Integration Theory, 3rd edn. Oxford University Press, Oxford, pp 64-84

Parguez A (2016) Economic theories of social order and the origins of the Euro. Int J Polit Econ 45(1):2-16

Patel KK (2020) The same point emerges. Project Europe, Cambridge University Press, Cambridge

Robbins L (1968) The economic causes of war [1939]. Howard Fertig, New York 
Scharpf F (2011) Monetary Union, fiscal crisis and the pre-emption of democracy. J Comp Govern Eur Policy 9(2):163-198

Schmitter P (2005) Ernst B. Haas and the legacy of neofunctionalism. J Eur Public Policy 12(2):255-272

Sinn HW, Wollmerhäuser T (2012) TARGET loans, current account balances and capital flows: the ECB's rescue facility. Int Tax Public Financ 19(4):468-508. See also: https://www.hanswernersinn. de/en/controversies/TargetDebate

Slobodian Q (2018) Globalists. Harvard University Press, Cambridge, MA

Tuck R (2020) The left case for Brexit: reflections on the current crisis. Polity, London

van Middelaar L (2013) The passage to Europe. Yale University Press, New Haven and London

Weiler JHH (1999) The constitution of Europe. Cambridge University Press, Cambridge

Publisher's Note Springer Nature remains neutral with regard to jurisdictional claims in published maps and institutional affiliations. 